\title{
Effect of Compost and Gypsum Application on the Chemical Properties and Fertility Status of Saline-Sodic Soil
}

\author{
Ghulam Sarwar, Muhammad Ibrahim ${ }^{2,3 *}$, Mukkram Ali Tahir ${ }^{1}$, Yasir Iftikhar ${ }^{1}$, \\ Muhammad Sajjad Haider, Noor-us-Sabah ${ }^{1}$, Kyung-Hwa Han ${ }^{3}$, \\ Sang-Keun $\mathrm{Ha}^{3}$, and Yong-Seon Zhang ${ }^{3}$ \\ ${ }^{1}$ University College of Agriculture, University of Sargodha, Sargodha (40100), Pakistan \\ ${ }^{2}$ Department of Environmental Sciences, Government College University, Faisalabad (38000), Pakistan \\ ${ }^{3}$ Department of Agricultural Environment, National Academy of Agricultural Science, Rural Development \\ Administration (RDA), Suwon (441-707), Republic of Korea
}

\begin{abstract}
Salt-affected soils are present in Pakistan in significant quantity. This experiment was conducted to assess the effectiveness of compost for reclamation and compare its efficiency with gypsum. For this purpose, various combinations of compost and gypsum were used to evaluate their efficacy for reclamation. A saline-sodic field having $\mathrm{pH}_{\mathrm{s}}$ 8.90, $\mathrm{EC}_{\mathrm{e}} 5.94 \mathrm{dS} \mathrm{m}^{-1}$ and SAR $34.5\left(\mathrm{mmol} \mathrm{L}^{-1}\right)^{1 / 2}$, SP (saturation percentage) $42.29 \%$ and texture Sandy clay loam, gypsum requirement (GR) $8.75 \mathrm{Mg} \mathrm{ha}^{-1}$ was selected for this study. The experiment comprised of seven treatments (control, gypsum alone, compost alone and different combinations of compost and gypsum based on soil gypsum requirements). Inorganic and organic amendments (gypsum and compost) were applied to a saline sodic soil. Rice and wheat crops were grown. Soil samples were collected from each treatment after the harvest of both crops and analyzed for chemical properties (electrical conductivity, soil reaction and sodium adsorption ratio) and fertility status (organic matter, available phosphorus and potassium contents) of soil. Results of this study revealed that compost and gypsum improved chemical properties (electrical conductivity, soil reaction and sodium adsorption ratio) of saline sodic soil to the desired levels. Similarly, all parameters of soil fertility like organic matter, available phosphorus and potassium contents were built up with the application of compost and gypsum.
\end{abstract}

Key words: Compost, Gypsum, Saline sodic soil, Chemical properties, Fertility status

\section{Introduction}

Soil salinity and sodicity are among the major constraints of present agriculture in Pakistan. About 6.68 million hectares of soils are affected to various degrees of salinity and/or sodicity in Pakistan (Khan, 1998). The area affected from slight to moderate problem is 1.83 million hectares which can be rehabilitated by using compost and other organic materials (Anonymous, 2003). Zaka et al. (2003) noticed a significant decrease in $\mathrm{EC}_{\mathrm{e}}, \mathrm{pH}$ and $\mathrm{SAR}$ of salt-affected soils due to application of organic amendments which was attributed to the formation of organic acids and resultant mobilization of native $\mathrm{Ca}^{+2}$. The

\footnotetext{
Received : May 17. 2011 Accepted : June 10. 2011

*Corresponding author : Phone: +82312900331

E-mail: ibrahim@rda.go.kr
}

physical properties namely bulk density, porosity and void ratio, hydraulic conductivity and water permeability were significantly improved when farm yard manure $\left(10 \mathrm{Mg} \mathrm{ha}^{-1}\right)$ was applied in combination with chemical amendments (Hussain et al., 2001). Thus, application of organic materials including compost can prove very useful in rehabilitation of salt-affected soils to the original potential along with significant improvement in physical conditions.

Many workers have described organic matter an important parameter of soil fertility and productivity. The soil organic matter has number of important roles to play in soil, both in its physical structure, sink for plant nutrients and medium for biological activities (Ibrahim et al., 2011; Iqbal et al., 2008) and thus has the greatest contribution towards productivity of soil. The provision of nutrients, improving soil water holding capacity and 
thus maintaining soil health and better aeration for seed germination and root development (Ibrahim et al., 2008; Ibrahim et al., 2010; Sarwar et al., 2008a). The use of compost has proved to improve soil organic matter status because it is rich source of nutrients and higher organic matter content. Depletion of nutrients and poor organic matter contents of Pakistani soils can only be replenished by applying compost to these soils (Sarwar et al., 2008a). In addition to improve fertility status of soil, compost can also be used for reclamation of salt-affected soils. Compost prepared from crop residues, leaves, grass clippings, plant stalks, wines, weeds, twigs and branches are very good alternative to mineral fertilizers which proved useful in many countries of the world. Use of compost has not only been adopted to enhance soil organic matter and enrich it in different nutrients but also to control the environmental pollution from debris (Sarwar et al., 2010).

Gypsum $\left(\mathrm{CaSO}_{4} \cdot 2 \mathrm{H}_{2} \mathrm{O}\right)$ is the most commonly used soil amendment under saline-sodic soils due to its availability at cheaper rates. Abrol et al. (1988) achieved the salinesodic soil amelioration through the combined effect of leaching and gypsum application. But this approach may not be useful to improve the physical and biological properties of already degraded soils. Madejon et al. (2001) reported a little effect on improvement of soil salinity and sodicity by the application of organic amendments alone. The applications of composts and gypsum have been reported to positively affect the soil properties and the present investigations have addressed the combined effect of compost and gypsum on the salinesodic soils under semi-arid conditions.

Burning of rice straw and wheat straw is the common practice adopted by farming community of this zone (South Asia). It was direly needed that this huge wastage of precious organic matter should be directed to a beneficial use through an appropriate research. According to Sarwar et al. (2008b) the grain yield and yield components (plant height, number of fertile tillers and 1000 grain weight) of rice and wheat increased significantly with the application of different organic materials but compost proved the most superior in this regard. Therefore, use of compost and gypsum alone and in combination may provide good strategy for improving soil chemical properties and fertility status of saline sodic soil. Keeping in view the situation of low organic matter status and huge amount of salt-affected soils in Pakistan, the present study was undertaken to evaluate the usefulness of compost and gypsum on soil chemical properties and fertility status of saline-sodic soil.

\section{Materials and methods}

The compost was prepared (organic matter $=48.15 \%$ and $\mathrm{C} / \mathrm{N}$ ratio $=13.33)$ and applied to the saline sodic field $\left[\mathrm{pH}_{\mathrm{s}}=8.90, \mathrm{EC}_{\mathrm{e}}=5.94 \mathrm{dS} \mathrm{m}^{-1}, \mathrm{SAR}=34.5(\mathrm{mmol}\right.$ $\left.\mathrm{L}^{-1}\right)^{1 / 2}$, organic matter $=0.20 \%$ and gypsum requirement $(\mathrm{GR})=8.75 \mathrm{Mg} \mathrm{ha}^{-1}$ ] alone and in combination with gypsum to determine its effect on soil chemical properties for reclamation. Randomized complete block design (RCBD) with three replications was applied to lay out the experiment. The treatment description is provided in Table 1. The various methods employed for the determination of soil properties were according to U.S. Salinity Laboratory Staff (1954) if otherwise mentioned. The method for compost preparation and application is described by Sarwar (2005).

Chemical properties of soil Soil samples were collected after the harvest of both crops (rice and wheat) and brought to the laboratory. All the soil samples were

Table 1. Treatments used and their description.

\begin{tabular}{cl}
\hline \hline Treatments & \multicolumn{1}{c}{ Description } \\
\hline T1 & Control (without compost and gypsum) \\
T2 & Gypsum at $100 \%$ of soil gypsum requirement $\left(3.50 \mathrm{t} . h a^{-1}\right)$ \\
T3 & Compost $24 \mathrm{Mg} \mathrm{ha}^{-1}$ \\
T4 & Compost at $24 \mathrm{Mg} \mathrm{ha}^{-1}+$ Gypsum at $100 \% \mathrm{GR}$ \\
$\mathrm{T} 5$ & Compost at $12 \mathrm{Mg} \mathrm{ha}^{-1}+$ Gypsum at $100 \% \mathrm{GR}$ \\
$\mathrm{T} 6$ & Compost at $24 \mathrm{Mg} \mathrm{ha}^{-1}+$ Gypsum at $50 \% \mathrm{GR}$ \\
$\mathrm{T} 7$ & Compost at $12 \mathrm{Mg} \mathrm{ha}^{-1}+$ Gypsum at $50 \% \mathrm{GR}$ \\
\hline
\end{tabular}

The treatments (compost and gypsum) were applied at the time of seed bed preparation before the sowing of wheat and transplanting of rice crops. 
analyzed for following chemical properties:

Electrical conductivity It was estimated by conductivity meter (LF-191 Conduktometer, Germany).

Soil reaction Soil $\mathrm{pH}$ (Jenway, UK) was used to determine the soil reaction.

Sodium adsorption ratio (SAR) SAR was calculated using the following formula:

$$
\mathrm{SAR}=\frac{\mathrm{Na}}{\sqrt{(\mathrm{Ca}+\mathrm{Mg}) / 2}}
$$

Where all cations are expressed in $\mathrm{mol}_{\mathrm{c}} \mathrm{L}^{-1}$ concentration.

\section{Fertility status of soil}

Soil organic matter Soil organic carbon was determined by titration of soil sample containing potassium dichromate and sulphuric acid using ferroin indicator. Organic matter was determined by applying following formula:

organic matter $(\%)=$ organic carbon $\times 1.72$

Available Phosphorus contents Olsen's method was followed to determine the available phosphorus contents in the soil using $\mathrm{NaHCO}_{3}$ solution as extracting agent. Standard stock $\mathrm{P}$ solution was prepared by dissolving exactly $0.439 \mathrm{~g} \mathrm{KH}_{2} \mathrm{PO}_{4}$ analytical grade in half liter distilled water. Then $25 \mathrm{ml} 1 \mathrm{~N} \mathrm{H}_{2} \mathrm{SO}_{4}$ were added and volume was made one litre to get $100 \mathrm{mg} \mathrm{kg}^{-1} \mathrm{P}$ standard stock solution. Soil sample of $2.5 \mathrm{~g}$ was weighed and 50 ml Olsen's reagent $\left(0.5 \mathrm{M} \mathrm{NaHCO}_{3}, \mathrm{pH}=8.5\right)$ was added and this suspension was shaken for 30 minutes and filtered. Five $\mathrm{ml}$ of the filtrate was used to develop color and then reading was noted using spectrophotometer.

Potassium contents It was determined with the help of a flame photometer (Jenway Model PFP-7). The instrument was first standardized with a series of standard solutions of $\mathrm{K}$ using analytical reagent $\mathrm{KCl}$ salt. After this, $\mathrm{K}$ was determined in the saturation extract.

Statistical analysis The data collected were subjected to analysis of variance techniques as described by Steel et al. (1997). Means were calculated and compared according to Duncan's Multiple Range Test (DMR Test) using Statistix 8.1.

\section{Results and Discussion}

\section{Chemical properties of soil}

Soil pH It was observed that application of gypsum and compost alone and in combination lowered the $\mathrm{pH}_{\mathrm{s}}$ of saline sodic soil significantly after rice and wheat crops (Fig. 1). After rice crop, the lowest $\mathrm{pH}$ value of 8.25 was observed in T4 (Compost at $24 \mathrm{Mg} \mathrm{ha}^{-1}+$ Gypsum at $100 \%$ GR) against the highest value of 8.75 in control (T1). After wheat crop, soil $\mathrm{pH}$ decreased in almost in the same pattern showing minimum $\mathrm{pH}$ value (8.22) for $\mathrm{T} 4$ in contrast to 8.71 for control. Soil $\mathrm{pH}$ elucidates an overall picture of the medium for plant growth including the trend of nutrient supply and the fate of applied nutrients, soil salinity and sodicity status, soil aeration, and ultimate weather conditions of the region. The $\mathrm{pH}$ numerical values are always within range of 8.0 to 8.4 under normal soil conditions in Pakistan. The decrease in soil $\mathrm{pH}$ always results in favorable soil medium and productivity by land management process and technique. The application of compost in combination with gypsum reduced the soil $\mathrm{pH}$ significantly as compared to control after harvesting rice and wheat (Sarwar et al., 2008a). Decrease in soil $\mathrm{pH}$ by the use of organic materials was also reported by other workers under the same agroecological conditions (Pattanayak et al., 2001; Smiciklas et al., 2002; Verma et al., 2002). The reason thereby the production of organic acids during mineralization of organic materials by heterotrophs and nitrification by autotrophs would have caused this decrease in soil $\mathrm{pH}$.

\section{Electrical conductivity $\left(\mathbf{E C}_{\mathrm{e}}\right)$ of saturated soil extracts} The data revealed that application of gypsum at 50\% GR in combination with compost at $12 \mathrm{Mg} \mathrm{ha}^{-1}$ (T7)

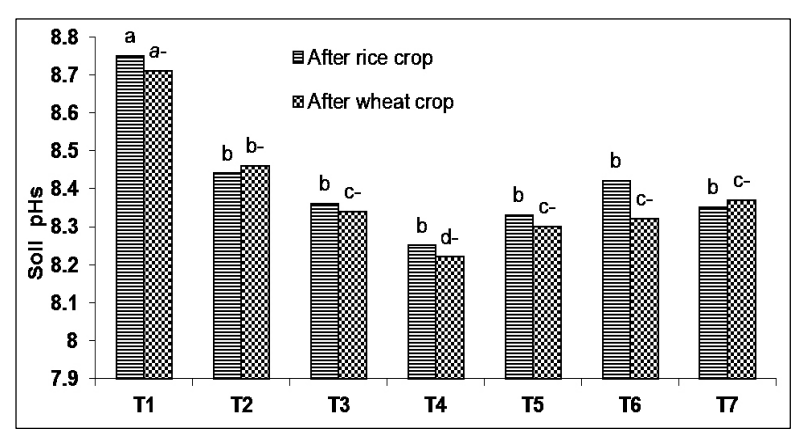

Fig. 1. Effect of compost and gypsum on soil $\mathrm{pH}_{\mathrm{s}}$ after rice and wheat crops. The bars sharing the same letters are statistical similar according to Duncan Multiple Range Test (DMRT) at $P<0.05$. 


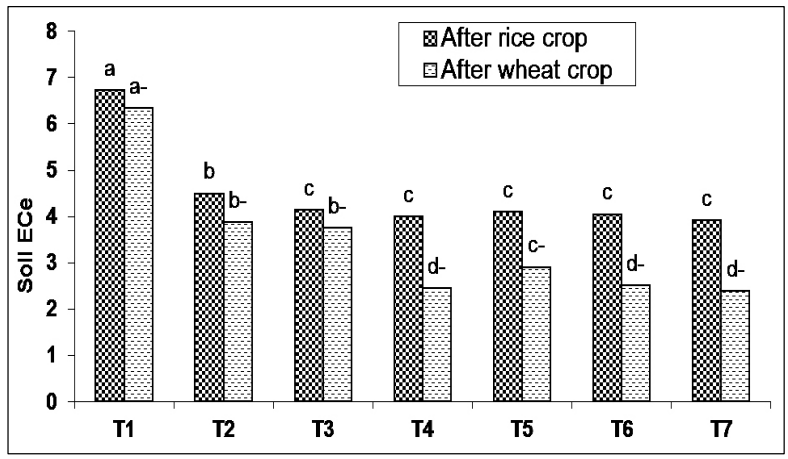

Fig. 2. Effect of compost and gypsum on soil $\mathrm{EC}_{\mathrm{e}}$ after rice and wheat crops. The bars sharing the same letters are statistical similar according to Duncan Multiple Range Test (DMRT) at $P<0.05$.

resulted in the lowest $\mathrm{EC}_{\mathrm{e}}$ of saline-sodic soil showing values of 3.92 and $2.93 \mathrm{dS} \mathrm{m}^{-1}$ after rice and wheat crops, respectively (Fig. 2). Control treatment (T1) recorded the highest value of $\mathrm{EC}_{\mathrm{e}}$ ( 6.73 and $6.35 \mathrm{dS} \mathrm{m}^{-1}$, respectively) after both rice and wheat crops. The differences among various treatments were significant when compared with control. However, in case of soil samples collected after rice crop, $\mathrm{T} 3$ (compost at $\mathrm{Mg} \mathrm{ha}^{-1}$ ), $\mathrm{T}_{4}$ (gypsum at 100\% GR + compost at $24 \mathrm{Mg} \mathrm{ha}^{-1}$ ), T5 (gypsum at $100 \% \mathrm{GR}+$ compost at $12 \mathrm{Mg} \mathrm{ha}^{-1}$ ), T6 (gypsum at $50 \% \mathrm{GR}+$ compost at $24 \mathrm{Mg} \mathrm{ha}^{-1}$ ) and $\mathrm{T} 7$ (gypsum at $50 \% \mathrm{GR}+$ compost at $12 \mathrm{Mg} \mathrm{ha}^{-1}$ ) were statistically at par with each other. Similarly, soil samples collected after wheat crop, T2 (gypsum at 100\% GR) and T3 (compost at $24 \mathrm{Mg} \mathrm{ha}^{-1}$ ) were at par statistically. Similarly, T 4 (gypsum at 100\% $\mathrm{GR}+$ compost at $24 \mathrm{Mg} \mathrm{ha}^{-1}$ ), T6 (gypsum at $50 \% \mathrm{GR}+$ compost at $24 \mathrm{Mg} \mathrm{ha}^{-1}$ ) and $\mathrm{T} 7$ (gypsum at $50 \% \mathrm{GR}+$ compost at $12 \mathrm{Mg} \mathrm{ha}^{-1}$ ) were also non-significant when adjudged statistically $(P>0.05)$. Electrical conductivity is a soil parameter that indicates indirectly the total concentration of soluble salts and is a direct measurement of salinity. A net decrease in EC of saline sodic soil was observed. The EC of such soils was already beyond the critical limit of $4.0 \mathrm{dS} \mathrm{m}^{-1}$. The main reason for this decrease in soil EC may be attributed to the leaching of soluble salts into lower profile. There are clear reports in the literature that physical properties (hydraulic conductivity, bulk density and total porosity) of saltaffected soils greatly improved when organic materials in the shape of manure or, compost are applied. Hussain et al. (2001) reported the improvement in soil physical properties with the application of farm manure $10 \mathrm{Mg} \mathrm{ha}^{-1}$ integrated with chemical amendments and also resulted

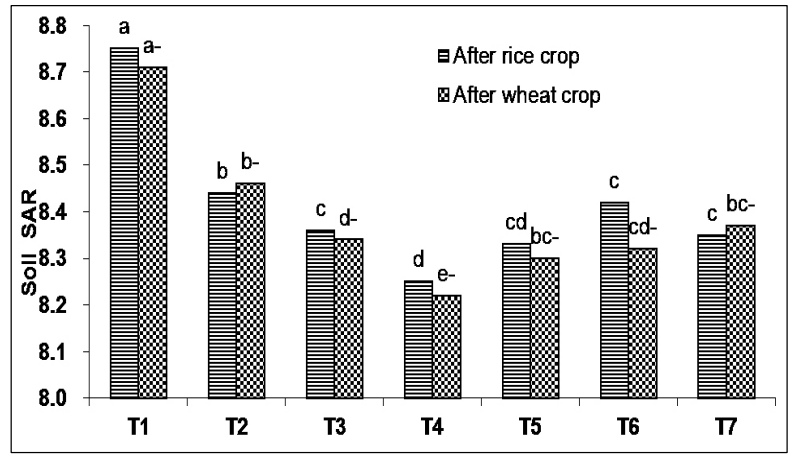

Fig. 3. Effect of compost and gypsum on soil SAR after rice and wheat crops. The bars sharing the same letters are statistical similar according to Duncan Multiple Range Test (DMRT) at $P<0.05$.

in enhanced rice and wheat yields under sodic soil conditions. Gypsum and organic matter in soil encourage granulation and increase cation exchange capacity (CEC) of soil and considered responsible for up to $90 \%$ adsorbing power of the soils. Application of gypsum also improved soil structure. The improved soil structure provided better environment for root development and aeration. Soil aggregation is quite often improved, which is attributed to the action of gum compounds, polysaccharides and fluvic acid components of organic matter. Such an improvement helps in leaching of soluble salts present in excessive quantities in the soil solution.

Sodium adsorption ratio (SAR) of soil It was observed that combined application of gypsum at $100 \%$ GR + compost at $24 \mathrm{Mg} \mathrm{ha}^{-1}\left(\mathrm{~T}_{4}\right)$ proved superior to all other treatments in reducing sodium adsorption ratio of soil after both rice and wheat crops exhibiting numerical values 11.50 and $10.48\left(\mathrm{mmol} \mathrm{L}^{-1}\right)^{1 / 2}$, respectively (Fig. 3). All treatments showed significant differences when compared with control. However, in case of rice crop, $\mathrm{T}_{3}$ (compost at $24 \mathrm{Mg} \mathrm{ha}^{-1}$ ), T5 (gypsum at 100\% GR + compost at $12 \mathrm{Mg} \mathrm{ha}^{-1}$ ), $\mathrm{T} 6$ (gypsum at $50 \% \mathrm{GR}+$ compost at $24 \mathrm{Mg} \mathrm{ha}^{-1}$ ) and $\mathrm{T} 7$ (gypsum at $50 \% \mathrm{GR}+$ compost at $12 \mathrm{Mg} \mathrm{ha}^{-1}$ ) remained at par statistically. In the same way, after wheat crop, T3 (compost at $24 \mathrm{Mg} \mathrm{ha}^{-1}$ ) proved non-significant for T6 (gypsum at $50 \%$ GR + compost at $24 \mathrm{Mg} \mathrm{ha}^{-1}$ ) while T2 (gypsum at $100 \% \mathrm{GR}$ ), T5 (gypsum at $100 \% \mathrm{GR}+$ compost at $12 \mathrm{Mg} \mathrm{ha}^{-1}$ ) and T7 (gypsum at $50 \% \mathrm{GR}+$ compost at $12 \mathrm{Mg} \mathrm{ha}^{-1}$ ) were also at par statistically. Many researchers have used sodium adsorption ratio as yardstick to measure the sodicity of a soil. A clear decrease in sodium adsorption ratio of the 
normal soil was recorded after rice as well as wheat crops. The effect of compost and gypsum was favorable over control. Studies of Zaka et al. (2003) and Sarwar et al. (2008a) also indicated the same trend of decrease in sodium adsorption ratio of soil with the use of FYM, rice straw and Sesbania green manure. The reduction in sodium adsorption ratio of soil with organic materials may be attributed to the slow release of organic acids causing mobilization of native $\mathrm{CaCO}_{3}$ in the calcareous soil. The sodium adsorption ratio is reduced either due to increase in divalent cations $(\mathrm{Ca}+\mathrm{Mg})$ due to reactions of organic acids with $\mathrm{CaCO}_{3}$ after the application of compost, FM and sesbania green manure or decrease in mono-valent cations $\left(\mathrm{Na}^{+}\right)$due to leaching (Sarwar et al., 2008a).

\section{Fertility status of soil}

Soil organic matter (SOM) Application of gypsum at $100 \% \mathrm{GR}+$ compost at $24 \mathrm{Mg} \mathrm{ha}^{-1}$ (T4) improved status of organic matter (\%) after rice as well as wheat crops (Fig. 4). The treatment $\mathrm{T} 3$ (compost at $24 \mathrm{Mg} \mathrm{ha}^{-1}$ ), $\mathrm{T} 4$ (gypsum at $100 \% \mathrm{GR}+$ compost at $24 \mathrm{Mg} \mathrm{ha}^{-1}$ ), $\mathrm{T} 5$ (gypsum at $100 \% \mathrm{GR}+$ compost at $12 \mathrm{Mg} \mathrm{ha}^{-1}$ ), T6 (gypsum at 50\% GR + compost at $24 \mathrm{Mg} \mathrm{ha}^{-1}$ ) and $\mathrm{T} 7$ (gypsum at $50 \% \mathrm{GR}+$ compost at $12 \mathrm{Mg} \mathrm{ha}^{-1}$ ) were statistically at par with each other. In case of wheat crop maximum organic matter (\%) was recorded in $\mathrm{T} 4$, where gypsum was applied at $100 \%$ GR along with compost at $24 \mathrm{Mg} \mathrm{ha}^{-1}$, while minimum in T1 (control). T2 (gypsum at $100 \%$ GR), T3 (compost at $24 \mathrm{Mg} \mathrm{ha}^{-1}$ ), T5 (gypsum at $100 \% \mathrm{GR}+$ compost at $12 \mathrm{Mg} \mathrm{ha}^{-1}$ ) and $\mathrm{T} 7$ (gypsum at $50 \%$ GR + compost at $12 \mathrm{Mg} \mathrm{ha}^{-1}$ ) were statistically non-significant when compared with each other.

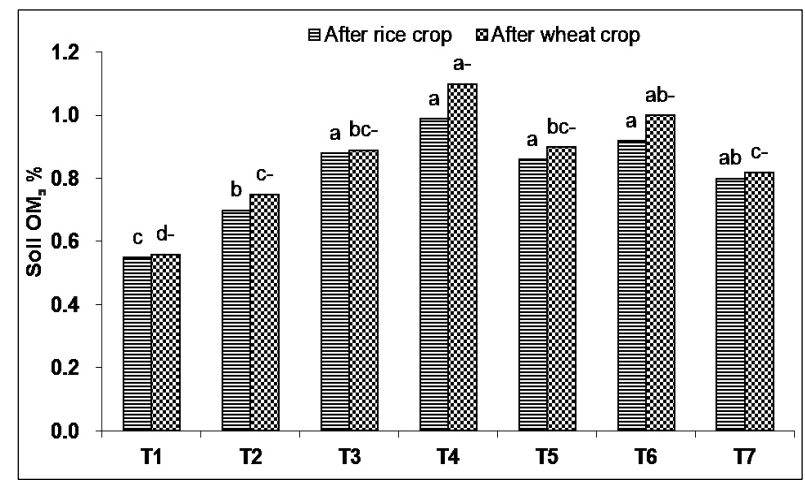

Fig. 4. Effect of compost and gypsum on soil organic matter after rice and wheat crops. The bars sharing the same letters are statistical similar according to Duncan Multiple Range Test (DMRT) at $P<0.05$.
Organic matter in soil is the ultimate source of nutrients for plant and soil microbial activity. It decides the fate of soil structure, water holding capacity, infiltration rate, aeration and porosity. The application of compost resulted in an increase of soil organic matter status (Sarwar et al., 2008a) under same soil conditions. The integrated use of compost and gypsum also proved helpful in increasing the organic matter level of the soil under saline and sodic conditions. Pattanayak et al. (2001); Singh et al. (2001); Selvakumari et al. (2000); Smiciklas et al. (2002), and Sarwar et al. (2010) reported similar results. Application of compost, FYM and Sesbania green manure resulted in overall increase of the soil organic matter level in case of different crops e.g. for maize (Iqbal et al., 2008). The status of organic matter in the soil had a relationship with the quantity applied.

Soil phosphomus The highest concentration of soil phosphorus was recorded with application of gypsum at $100 \%$ GR along with compost at $24 \mathrm{Mg} \mathrm{ha}^{-1}$ (T4) both after rice and wheat crops (Fig. 5). The treatments differed from control significantly in terms of statistics. The use of control proved inferior to all other treatments both after rice and wheat crops. In case of wheat crop treatments T3 (compost at $24 \mathrm{Mg} \mathrm{ha}^{-1}$ ) and $\mathrm{T} 5$ (gypsum at $100 \% \mathrm{GR}+$ compost at $12 \mathrm{Mg} \mathrm{ha}^{-1}$ ) were statistically non-significant. All other treatments were significant statistically when compared with each other. In case of rice crop treatments T2 (gypsum at $100 \% \mathrm{GR}$ ), T3 (compost at $24 \mathrm{Mg} \mathrm{ha}^{-1}$ ), T4 (gypsum at $100 \% \mathrm{GR}+$ compost at $24 \mathrm{Mg} \mathrm{ha}^{-1}$ ), T5 (gypsum at $100 \% \mathrm{GR}+$ compost at $12 \mathrm{Mg} \mathrm{ha}^{-1}$ ), $\mathrm{T} 6$ (gypsum at $50 \% \mathrm{GR}+$ compost at $24 \mathrm{Mg} \mathrm{ha}^{-1}$ ) and $\mathrm{T}_{7}$ (gypsum at $50 \% \mathrm{GR}+$ compost at $12 \mathrm{Mg} \mathrm{ha}^{-1}$ ) remained

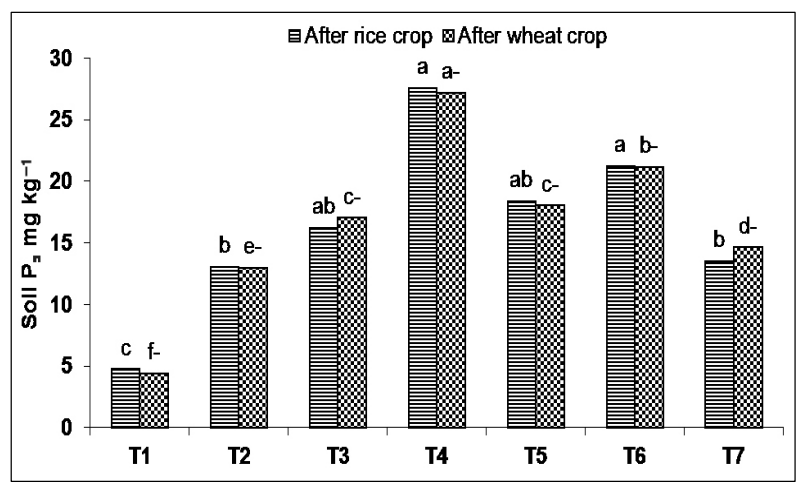

Fig. 5. Effect of compost and gypsum on soil phosphorous after rice and wheat crops. The bars sharing the same letters are statistical similar according to Duncan Multiple Range Test (DMRT) at $P<0.05$. 
statistically at par. Phosphorus is second major nutrient element for plant growth and an integral part of energy rich molecules ADP and ATP which are involved in almost all energy transformations in plants. The $\mathrm{P}$ availability is the most dynamic in the soil and besides other factors; its availability is also controlled by soil $\mathrm{pH}$, clay content, calcareousness and soil organic matter content. The application of an organic source of nutrition breaks the bond between phosphorus compounds and $\mathrm{CaCO}_{3}$ keeping it as at higher amounts in available form. Some workers have determined the soil phosphorus availability by using various organic materials and their findings supported the present results (Pattanayak et al., 2001; Pramer and Sharma, 2002; Verma et al., 2002; Singh et al., 2002).

Soil potassium The Fig. 6 revealed that control treatment (T1) remained inferior in enhancing soil potash status when compared with other treatments. In case of rice crop, maximum concentration of soil potash $(72 \mathrm{mg}$ $\mathrm{kg}^{-1}$ ) was analyzed in T4, where gypsum was applied at $100 \%$ GR along with compost at $24 \mathrm{Mg} \mathrm{ha}^{-1}$ against the minimum concentration $\left(29 \mathrm{mg} \mathrm{kg}^{-1}\right)$ for T1. Treatments T2 (gypsum at 100\% GR), T5 (gypsum at 100\% GR + compost at $12 \mathrm{Mg} \mathrm{ha}^{-1}$ ) and $\mathrm{T} 7$ (gypsum at $50 \% \mathrm{GR}+$ compost at $12 \mathrm{Mg} \mathrm{ha}^{-1}$ ) remained at par statistically among each other. Similarly treatments T3 (compost at $24 \mathrm{Mg}$ ha ${ }^{1}$ ), T4 (gypsum at $100 \% \mathrm{GR}+$ compost at $24 \mathrm{Mg} \mathrm{ha}^{-1}$ ) and T6 (gypsum at $50 \% \mathrm{GR}+$ compost at $24 \mathrm{Mg} \mathrm{ha}^{-1}$ ) were also non-significant statistically when compared with each other. In case of wheat crop, differences among various treatments were noticed significant statistically among each other except T5 (gypsum at 100\% GR + compost at $12 \mathrm{Mg} \mathrm{ha}^{-1}$ ) and $\mathrm{T} 7$ (gypsum at $50 \% \mathrm{GR}+$ compost at $12 \mathrm{Mg} \mathrm{ha}^{-1}$ ), which were non-significant statistically when compared with each other. Soil potash is found in different forms as readily available and water soluble, exchangeable and fixed as part of clay micelle and tends to stay in equilibrium. The compost application affects the soil potash availability (Sarwar et al., 2008a). The effect is positive resulting in more availability of $\mathrm{K}^{+}$to the plants. The hydrogen ions released from organic materials are exchanged with $\mathrm{K}$ on exchange site or set free from the fixed site of the clay micelle. Thus, the overall status of soil regarding availability of potassium

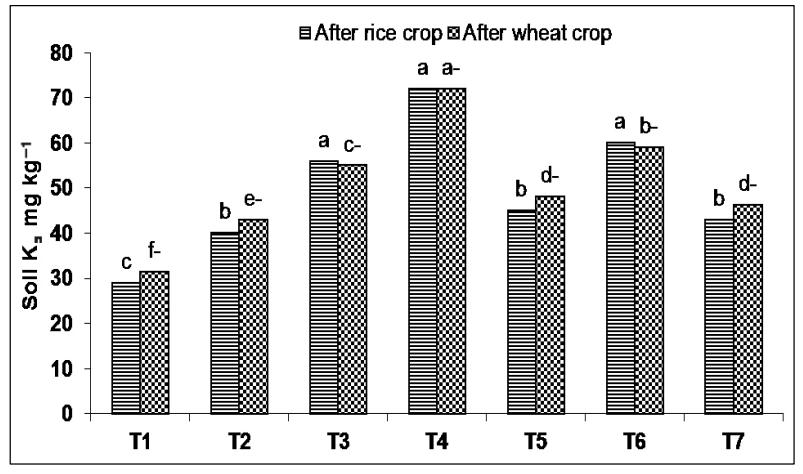

Fig. 6. Effect of compost and gypsum on soil potassium after rice and wheat crops. The bars sharing the same letters are statistical similar according to Duncan Multiple Range Test (DMRT) at $P<0.05$.

content is improved. Research conducted by other scientists proved the above hypothesis (Selvakumari et al., 2000; Singh et al., 2001; Singh et al., 2002; Verma et al., 2002) also reported that continuous use of chemical fertilizers, FYM, compost and green manure enhanced the potassium status in the soil.

\section{Conclusions}

Rice-wheat system is very popular in Pakistan and is being practiced around the globe under various agroecological conditions. The integrated use of organic and chemical sources of nutrients has increased the soil fertility and may increase the soil and plant productivity. The easily available wheat straw coupled with animal dung and crop residues instead should be used as nutrient source and amendment for soil quality improvement instead of burning or wasting otherwise. The value added compost will not only supplement the chemical fertilizers but also reduce the environmental pollution saving in cost of production by the resource poor farmers and resultantly improvement in soil quality and soil productivity.

\section{Acknowledgements}

The support by Post-doctoral Fellowship Program (Project No. PJ00605012011) of National Academy of Agricultural Science, Rural Development Administration, Republic of Korea is highly acknowledged. 


\section{References}

Abrol, I.P., J.S.P. Yadav, and F.I. Massoud. 1988. Salt-affected soils and their management. FAO Soils Bulletin. Soil Resources, Management and Conservation Service, FAO Land and Water Development Division, 39: pp.131.

Anonymous, 2003. Agricultural Statistics of Pakistan. Government of Pakistan, Ministry of Food, Agriculture \& Livestock (Economic Wing), Islamabad.

Brady, N.C. 2005. The Nature and properties of soil (13th Ed.). Macmillan Publishing Co. New York.

Hussain, N., G. Hassan, A. Ghafoor, and G. Sarwar. 1998. Bioamelioration of sandy clay loam saline sodic soil. Proc. $6^{\text {th }}$ Intl. Micro-Irrigation Congress, March 8-10, 1998, Florida, p. 293-300.

Hussain, N., G. Hassan, M. Arshadullah, and F. Mujeeb. 2001. Evaluation of amendments for the improvement of physical properties of sodic soil. Intl. J. Agric. Bio. 3:319-322.

Ibrahim, M., A. Hassan, M. Arshad, and A. Tanveer. 2010. Variation in root growth and nutrient element of wheat and rice: effect of rate and type of organic materials. Soil \& Environ. 29:47-52.

Ibrahim, M., A. Hassan, M. Iqbal, and E.E. Valeem. 2008. Response of wheat growth and yield to various levels of compost and organic manure. Pak. J. Bot. 40:2135-2141.

Ibrahim, M., M. Yamin, G. Sarwar, A. Anayat, F. Habib, S. Ullah, and S. Rehman. 2011. Tillage and farm manure affect root growth and nutrient uptake of wheat and rice under semi-arid conditions of Pakistan. Appl. Geochem. 26:S194S197.

Iqbal, M., A. Hassan, and M. Ibrahim. 2008. Effects of tillage systems and mulch on soil physical quality parameters and maize (Zea mays L.) yield in semi-arid Pakistan. Biol. Agric. Hort. 25:311-325.

Khan, G.S. 1998. Soil salinity/sodicity status in Pakistan. Soil Survey of Pakistan, Lahore, 59p.

Madejon, E., R. Lopes, Y.M. Murillo, and F. Cabrera. 2001. Agricultural use of three (sugar - beet) vinasse compost: effect on crops and chemical properties of a cambisol soil in the Quadalquivirm river valley (SW Spain). Agric. Ecosystems and Environ. 84:55-65.

Parmer, D.K. and V. Sharma. 2002. Studies on long-term application of fertilizers and manure on yield of maize-wheat rotation and soil properties under rain-fed conditions in Western-Himalayas. J. Indian Soc. Soil Sci. 50:311-312.

Pattanayak, S.K., K.N. Mishra, M.K. Jena, and R.K. Nayak.
2001. Evaluation of green manure crops fertilized with various phosphorus sources and their effect on subsequent rice crop. J. Indian Soc. Soil Sci. 49:285-291.

Sarwar, G. 2005. Use of compost for crop production in Pakistan. Ökologie und Umweltsicherung. 26/2005. Universität Kassel, Fachgebiet Landschaftsökologie und Naturschutz, Witzenhausen, Germany.

Sarwar, G., H. Schmeisky, N. Hussain, S. Muhammad, M. Ibrahim, and E. Safdar. 2008a. Improvement of soil physical and chemical properties with compost application in rice-wheat cropping system. Pak. J. Bot. 40:275-282.

Sarwar, G., N. Hussain, H. Schmeisky, and S. Muhammad, M. Ibrahim and S. Ahmad. 2008b. Efficiency of various organic residues for enhancing rice-wheat production under normal soil conditions. Pak. J. Bot. 40:2107-2113.

Sarwar, M.A., M. Ibrahim, M. Tahir, K. Ahmad, Z.I. Khan, and E.E. Valeem. 2010. Appraisal of pressmud and inorganic fertilizers on soil properties, yield and sugarcane quality. Pak. J. Bot. 42:1361-67.

Selvakumari, G., M. Baskar, D. Jayanthi, and K.K. Mathan. 2000. Effect of integration of fly-ash with fertilizers and organic manures on nutrient availability, yield and nutrient uptake of rice in alfisols. J. Indian Soc. Soil Sci. 48:268-278.

Singh, M., V.P. Singh, and K.S. Reddy. 2001. Effect of integrated use of fertilizer nitrogen and farmyard manure or green manure on transformation of $\mathrm{N}, \mathrm{K}$ and $\mathrm{S}$ and productivity of rice-wheat system on a vertisol. J. Indian Soc. Soil Sci. 49:430-435.

Singh, S., R.N. Singh, J. Prasad, and B. Kumar. 2002. Effect of green manuring, FYM and bio-fertilizer in relation to fertilizer nitrogen on yield and major nutrient uptake by upland rice. J. Indian Soc. Soil Sci. 50:313-314.

Smiciklas, K.D., P.M. Walker, and T.R. Kelley. 2002. Utilization of compost (food, paper, landscape and manure) in row crop production. Department of Agriculture and Health Sciences, Illinois State University, USA.

Steel, R.G.D., J.H. Torrie, and D.A. Dickie. 1997. Principles and procedures of statistics-A biometric approach, third ed. McGraw-Hill Publishing Co., Toronto.

Verma, T.S., V.K. Suri, and J. Paul. 2002. Prescription-based fertilizer recommendations for rice, maize and wheat in different agro-climatic zones of Himachal Pradesh. J. Indian Soc. Soil Sci. 50:272-277.

U.S. Salinity Laboratory Staff. 1954. Diagnosis and improvement of saline and alkali soils. USDA Handbook, Vol. 60. US Government Printing Office. Washington, DC. pp. 159.

Zaka, M.A., F. Mujeeb, G. Sarwar, N.M. Hassan, and G. Hassan. 2003. Agro-melioration of saline sodic soils. Online J. Biol. Sci. 3:329-334. 